\title{
PARADIGMA BARU PENDIDIKAN ISLAM DALAM UPAYA MENJAWAB TANTANGAN GLOBAL
}

\author{
Oleh: Muh. Sain Hanafy*
}

\begin{abstract}
The problems faced by education nowadays in implementation teaching and learning prosess is the failure of Islamic education occuring in Islamic instution. This is because of the application of education which is merely concentrating on cognitive aspect including the willingness to apply the value of Islamic teaching. The development of Islamic education must rely on new paradigms that education has appreciation to democracy, individual differences, equality, diversity and involving society in decision making toward policy of education.
\end{abstract}

KEYWORDS: Paradigma baru, pendidikan Islam, tantangan global

KETIKA wajah pendidikan di Indonesia dewasa ini ditatap, tampak wajah yang pucat-pasih dan suram, karena berbagai tragedi mewarnai rona hidup dan kehidupannya. Mulai perilaku dari siswa, mahasiswa sampai demonstrasi para guru dan pendidik lainnya yang menuntut tunjangan mereka dinaikkan. Hal ini merupakan kenyataan dan fenomena sosial yang tidak dapat dibantah lagi, betapa rapuhnya dunia pendidikan di negara ini yang nyaris kehilangan rohnya. Ini semua merupakan representasi dari keadaan sistem pendidikan yang sekularistik-materialistik.

Dampak terhadap kondisi itu tampak ketika masyarakat Indonesia mengalami krisis multidimensional dalam aspek kehidupan. Fenomena kemiskinan, kebodohan, kezaliman, penindasan, ketidakadilan di segala bidang, kemerosotan moral, peningkatan tindak kriminal, dan berbagai bentuk patalogi sosial lainnya telah menjadi bagian tak terpisahkan dari kehidupan masyarakat. Akibat krisis ekonomi yang berkepanjangan, puluhan juta orang terpaksa hidup dalam kemiskinan dan belasan juta orang kehilangan pekerjaan. Sementara, sekitar 4,5 juta anak harus putus sekolah. Hidup semakin tidak mudah dijalani, sekalipun sekedar untuk mencari sesuap nasi. ${ }^{1}$

*Kandidat doktor pada Program Pascasarjana UIN Alauddin ini adalah dosen Fakultas Tarbiyah dan Keguruan UIN Alauddin Makassar. Ia meraih Magister Pendidikan dari Program Pascasarjana Universitas Negeri Makassar. 
Keyakinan umat Islam bahwa berbagai krisis tersebut merupakan fasad (kerusakan) yang ditimbulkan karena perilaku manusia sendiri. Allah swt. berfirman dalam: Q.S. al-Rūm (30): 41 sebagai berikut:

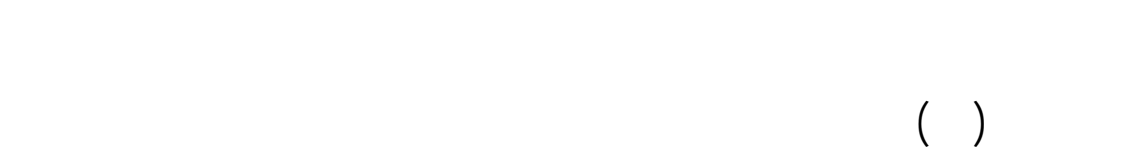

Telah nampak kerusakan di darat dan di laut disebabkan karena perbuatan tangan manusia, supaya Allah merasakan kepada mereka sebahagian dari (akibat) perbuatan mereka, agar mereka kembali (ke jalan yang benar). ${ }^{2}$

Ayat lain pada Q.S. al-Nahl (16): 112 mengatakan:

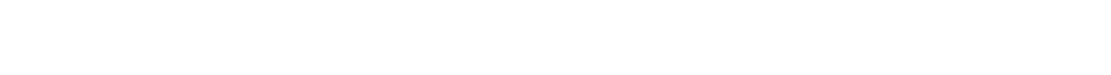

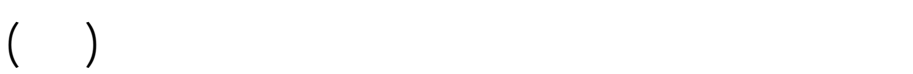

Dan Allah telah membuat suatu perumpamaan (dengan) sebuah negeri yang dahulunya aman lagi tenteram, rezkinya datang kepadanya melimpah ruah dari segenap tempat, tetapi (penduduk) nya mengingkari nikmat-nikmat Allah, oleh karena itu Allah merasakan kepada mereka pakaian kelaparan dan ketakutan, disebabkan apa yang selalu mereka perbuat. ${ }^{3}$

Sebagai negara yang berpenduduk mayoritas muslim, pendidikan Islam mempunyai peran yang sangat signifikan di Indonesia dalam pengembangan sumber daya manusia dan pembangunan karakter, sehingga masyarakat yang tercipta merupakan cerminan masyarakat Islam. Dengan demikian, Islam benar-benar menjadi rahmatan lil'alamin (rahmat bagi seluruh alam).

Namun, hingga kini pendidikan Islam masih saja menghadapi permasalahan yang kompleks, dari permasalahan konseptual-teoritis hingga persoalan operasional-praktis. Tidak terselesaikannya persoalan ini menjadikan pendidikan Islam tertinggal dari lembaga pendidikan lainnya, baik secara kuantitatif maupun kualitatif, sehingga pendidikan Islam terkesan sebagai pendidikan "kelas dua". Tidak heran jika kemudian banyak dari generasi muslim yang justru menempuh pendidikan di lembaga pendidikan non Islam.

Berdasarkan beberapa uraian di atas, maka dalam artikel ini akan dibahas seputar tantangan pendidikan Islam kini dan di sini serta paradigma baru menjawab tantangan pendidikan Islam di era globalisasi.

\section{TANTANGAN PENDIDIKAN ISLAM KINI DAN DI SINI}

Melihat judul tersebut di atas tentu saja wilayahnya sangat luas. Oleh sebab itu, penulis membatasi "diri" dalam membahasnya secara holistik 
dan komprehensif, tidak dengan secara parsial. Artinya, penulis tentu saja tidak akan menyorot secara rinci problematika interen an sich lembaga pendidikannya, tetapi lebih kepada menyeluruh dengan berkaca pada kondisi fenomenal di Indonesia.

Salah satu cara untuk mengetahui problematika pendidikan Islam di Indonesia sebagai bagian dari seluruh jenis pendidikan yang ada adalah dengan mengkaji persoalan yang terdapat dalam dunia pendidikan Islam. Problematika dunia pendidikan di Indonesia seakan tiada habisnya. Ibarat benang kusut yang sulit diurai kembali, sejumlah permasalahan klasik masih saja melingkupi dunia pendidikan Indonesia, tidak hanya masalah pemerataan kesempatan pendidikan, peningkatan kualitas dan fasilitas, namun juga rendahnya tingkat relevansi pendidikan dengan kebutuhan dunia kerja.

Yaumi C.A. Achir mengatakan bahwa bergesernya struktur masyarakat dari yang tradisional ke yang modern, dari masyarakat agraris ke masyarakat industri, maka terbuka pula berbagai job baru yang memerlukan berbagai jenis keterampilan dan keahlian. Untuk menghadapi semua ini, tentu saja kurikulum di setiap lembaga pendidikan harus disesuaikan dengan perkembangan zaman. ${ }^{4}$

Dalam hal tersebut di atas, Yaumi lebih lanjut mengatakan bahwa untuk menghadapi tuntutan masa depan diperlukan curriculum reform untuk jenjang pendidikan menengah umum maupun kejuruan. Perlu diingat bahwa perubahan-perubahan yang akan terjadi di dunia kerja harus diperhitungkan oleh para perencana pendidikan, bukan hanya diarahkan kepada segi bobot materi, tetapi juga dari segi moral. ${ }^{5}$

Problematika kurikulum pendidikan di Indonesia misalnya diarahkan kepada kurikulum yang memberikan bekal kepada peserta didik untuk mampu mendapatkan pekerjaan yang menghasilkan pendapatan yang lebih besar. Kurikulum tersebut menurut hemat penulis dibuat sedemikian rupa dan untuk mengikutinya harus membutuhkan dana yang sangat besar. Jika dalam proses memperolehnya harus mengeluarkan dana yang besar, dapat dibayangkan efek setelah memperoleh pengetahuan tersebut. Peserta didik yang telah selesai akan menggunakan pengetahuan tersebut paling tidak untuk mengembalikan modal dan tentu berupaya untuk mendapatkan untung sebesar-besarnya. Karena memang teori modern mengatakan bahwa pendidikan adalah investasi masa depan. Prinsip ini bukanlah hal yang baru terdengar, bahkan prinsip ekonomi yang diajarkan di sekolah menengah mengatakan "keluarkan modal sesedikit mungkin dan hasilkan keuntungan sebesar-besarnya". Hal tersebut memang tidak semua salah, tetapi ketika moral spiritual dimarginalkan maka pendidikan itu 
sendiri akan menghasilkan generasi terpelajar yang beridiologi materialisme-kapitalisme, bahkan sekularisme.

Uraian tersebut di atas senada dengan ungkapan Ainurrafiq Dawam bahwa pendidikan Indonesia saat ini merupakan hasil kebijakan politik pemerintah Indonesia selama ini. Mulai dari pemerintahan Orde Lama, Orde Baru, dan Orde Reformasi saat ini. Pendidikan Indonesia masih lebih mementingkan pendidikan yang bersifat dan beridiologi materialismekapitalisme bahkan sekularisme. Idiologi pendidikan yang demikian ini memang secara teoritis tidak tampak, akan tetapi secara praktis merupakan realitas yang tak dapat dibantah lagi. Materialisasi atau proses menjadikan semua bernilai materi telah merusak segala sendi sistem pendidikan Indonesia, termasuk pendidikan Islam. Sendi-sendi yang dimasuki bukan hanya dalam materi pelajaran, pendidik, peserta didik, manajemen, dan lingkungan, akan tetapi tujuan pendidikan itu sendiri. Jika tujuan pendidikan telah terfokus ke hal-hal yang bersifat materi maka apa yang diharapkan dari proses pendidikan tersebut. ${ }^{6}$

Analisis tersebut di atas tentu saja mengundang kontroversi, bahkan menuding bahwa teori tersebut terlalu tendensius, karena jarang memang orang mengakui dengan jujur bahwa sistem pendidikan di Indonesia sistem yang sekuler, materialistik dan kapitalistik. Biasanya yang dijadikan argumentasi adalah UU Sisdiknas No. 20 tahun 2003 pasal 4 ayat 1 yang berbunyi, "Pendidikan nasional bertujuan membentuk manusia yang beriman dan bertaqwa kepada Tuhan Yang maha Esa, berakhlak dan berbudi mulia, sehat, berilmu, cakap, serta menjadi warga negara yang demokratis dan bertanggung jawab. ${ }^{7}$

Akan tetapi, menurut penulis yang perlu diingat bahwa sekularisme bukan berarti otomatis anti agama. Tidak selalu anti "iman" dan anti "takwa". Sekularisme itu hanya menolak peran agama untuk mengatur kehidupan publik, termasuk aspek pendidikan. Jadi, selama agama hanya "pelengkap penderita" atau tidak dijadikan asas untuk menata kehidupan publik seperti sebuah sistem pendidikan maka sistem pendidikan itu tetap sistem pendidikan sekular, walaupun tentu saja para individu pelaksana sistem itu beriman dan bertakwa.

Sebuah analisis yang mendukung pernyataan tersebut di atas dikemukakan oleh Briyan S. Turner yang mengatakan bahwa pengawasan sekuler terhadap pendidikan agama bukan ditujukan untuk menghilangkan Islam, melainkan untuk menghilangkan hubungan agama dan pendidikan agama dari nilai-nilai lembaga pendidikan tradisional. ${ }^{8}$

Sesungguhnya diakui atau tidak, sistem pendidikan di Indonesia kini adalah sistem sekuler materialistik. Hal ini dapat dibuktikan antara lain 
pada UU Sisdiknas Nomor 20 Tahun 2003 Bab VI tentang jalur, jenjang dan jenis pendidikan bagian kesatu (umum) pasal 15 yang berbunyi, "Jenis pendidikan mencakup pendidikan umum, kejuruan, akademik, profesi, advokasi, keagamaan, dan khusus."9

Pada pasal ini tampak jelas adanya dikotomi pendidikan, yaitu pendidikan agama dan pendidikan umum. Sistem pendidikan dikotomis semacam ini terbukti telah gagal melahirkan manusia yang berkepribadian luhur dan saleh, sekaligus mampu menjawab tantangan perkembangan melalui penguasaan sains dan teknologi di era globalisasi saat ini.

Selanjutnya, lebih tampak lagi pada Bab X pasal 37 UU Sisdiknas tentang ketentuan kurikulum pendidikan dasar dan menengah yang mewajibkan memuat sepuluh bidang mata pelajaran dengan pendidikan agama yang tidak proporsional dan tidak dijadikan landasan bagi bidang pelajaran yang lainnya.

Hal ini jelas tidak akan mampu melahirkan anak didik yang sesuai dengan tujuan dari pendidikan nasional sendiri, yaitu mewujudkan suasana belajar dan proses pembelajaran agar peserta didik secara aktif mengembangkan diri, kepribadian, kecerdasan, akhlak mulia, serta keterampilan yang diperlukan dirinya, masyarakat, bangsa dan negaranya. Kacau balaunya kurikulum ini tentu saja berawal dari asasnya yang sekuler yang kemudian mempengaruhi penyusunan struktur kurikulum yang tidak memberikan ruang yang semestinya bagi proses penguasaan tsaqāfah Islam dan pembentukan kepribadian muslim.

Dampak yang ditimbulkan sistem pendidikan sekuler-materialistik ini memang bisa melahirkan orang pandai yang menguasai sains-teknologi melalui pendidikan umum yang diikutinya, akan tetapi terbukti gagal dalam membentuk kepribadian muslim dan tidak sedikit menjadi koruptor kelas kakap. Demikian halnya mereka yang belajar di lingkungan agama memang menguasai tsaqäfah Islam dan secara relatif sisi kepribadiannya tergarap baik, akan tetapi di sisi lain, ia buta terhadap perkembangan sains dan teknologi.

Selanjutnya, khusus lembaga pendidikan Islam pada kondisi sekarang sangat ketinggalan dengan lembaga pendidikan lainnya sebagaimana dikemukakan oleh Azyumardi Azra bahwa paling tidak ada lima penyebab utamanya: Pertama pendidikan Islam sering terlambat merumuskan diri untuk merespons perubahan dan kecenderungan masyarakat sekarang dan akan datang. Kedua Sistem pendidikan Islam kebanyakan masih cenderung mengorientasikan diri di bidang-bidang humaniora dan ilmuilmu sosial. Ketiga usaha pembaharuan pendidikan Islam sering bersifat sepotong-sepotong dan tidak komprehensif sehingga tidak terjadi peru- 
bahan yang esensial. Keempat pendidikan Islam tetap berorientasi pada masa silam ketimbang berorientasi kepada masa depan, atau kurang versifat future oriented. Kelima sebagian pendidikan Islam belum dikelola secara professional, baik dalam tenaga pengajar, kurikulum maupun pelaksanaan pendidikannya. ${ }^{10}$

Analisis dari fenomena permasalahan pendidikan Islam tersebut di atas adalah sebuah realiatas kini dan disini (zaman sekarang di Indonesia). Ketika lembaran sejarah Islam dibuka sebagai laboratorium untuk membuktikan sebuah realitas kebenaran masa silam, mereka bangga bahwa ternyata pernah memiliki para pemikir dan ilmuan-ilmuan besar dan mempunyai kontribusi yang besar pula bagi pembangunan peradaban dan ilmu pengetahuan dunia. Namun, di sisi lain, kini diperhadapkan kepada sebuah kenyataan bahwa pendidikan Islam tidak berdaya dalam realitas masyarakat industri dan teknologi modern. Kenyataan itu didukung oleh pandangan ekstrim dari sebagian umat Islam yang kurang meminati ilmuilmu umum dan bahkan sampai ke tingkat "diharam-kannya". Hal ini tentu saja berdampak pada pembelajaran dalam sistem pendidikan Islam yang masih berkutat pada teks. Pendidikan hanya bergelut dengan setumpuk teks-teks keagamaan yang sebagaian besar berbicara seputar hukumhukum Islam (fiqh) semata.

Hal ini seirama dengan pernyataan Muhaimin bahwa tantangan umat Islam pada prinsipnya ada dua faktor, yaitu: pertama, dha'fu al-ìmān wa al-akhlāq (lemahnya iman dan akhlak umat). Indikatornya adalah di antaranya umat Islam banyak yang bersikap diam dalam menghadapi kenyataan-kenyataan sosial yang membawa kerusakan iman dan moral, atau bahkan bersifat permissive (serba membolehkan). Kedua, dha'fu al-'ilmi (lemahnya ilmu pengetahuan). Indikatornya adalah: (a) terdapat lebih kurang 500 ayat berbicara tentang hukum (fikih) yang sudah dikaji oleh para ulama, tetapi ada sekitar 750 ayat yang berbicara tentang sains dan teknologi, tetapi belum berhasil dibedah dan dikaji secara intens oleh ulama dan ilmuan Islam masa kini; (b) referensi sebagai bahan rujukan dari karya ilmiah para ilmuan kebanyakan dikutip dari buku-buku non Islam dari para ulama sebagai indikator sebuah tulisan ilmiah. ${ }^{11}$

Terkait dengan ketertinggalan pendidikan Islam, dalam buku Pemikiran Pendidikan Islam: Kajian Filosofis dan Kerangka Dasar Operasionalnya, Muhaimin dan Abd. Mujib mengatakan bahwa terjadinya krisis pendidikan Islam di Indonesia dikarenakan penyempitan terhadap pemahaman pendidikan Islam. Pendidikan Islam dimaknai hanya berkisar pada aspek kehidupan ukhrawi yang terpisah dari kehidupan duniawi, atau aspek kehidupan rohani yang terpisah dari kehidupan jasmani. ${ }^{12}$ 
Dari pendapat Muhaimin ini, tampak adanya perbedaan dan pemisahan antara yang dianggap agama dan bukan agama, yang sakral dan yang profan, antara dunia dan akherat. Cara pandang yang memisahkan antara satu dengan yang lain ini disebut sebagai cara pandang dikotomik .

Problematika pendidikan dewasa ini ketika ditilik dari operasionalisasi proses pembelajarannya, Muchtar Buchori berpendapat bahwa terjadinya kegagalan pendidikan agama di lembaga pendidikan Islam disebabkan oleh praktek pendidikannya hanya memperhatikan aspek kognitif semata dari pertumbuhan kesadaran nilai-nilai (agama). Ia mengabaikan aspek afektif dan konatif-volutif, yakni kemauan dan tekad untuk mengamalkan nilai-nilai ajaran agama. ${ }^{13}$ Dalam pada itu, Kamaruddin Hidayat berpendapat bahwa pendidikan agama lebih berorientasi pada belajar tentang agama dan kurang berorientasi pada belajar bagaimana cara beragama dengan baik dan benar. ${ }^{14}$

Analisis tersebut di atas senada dengan pernyataan Harun Nasution bahwa pendidikan agama (Islam) banyak dipengaruhi oleh trend Barat, yang lebih mengutamakan pengajaran daripada pendidikan moral, padahal intisari pendidikan agama adalah pendidikan moral. ${ }^{15}$

Dalam membincangkan seputar kualitas guru (pendidik), keadaan guru di Indonesia juga sangat memprihatinkan. Kebanyakan guru belum memiliki profesionalitas yang memadai untuk menjalankan tugasnya sebagaimana disebutkan dalam pasal 39 UU Nomor 20/2003. Undang-undang tersebut pada intinya merencanakan pembelajaran, melaksanakan pembelajaran, menilai hasil pembelajaran, melakukan bimbingan, melakukan pelatihan, melakukan penelitian, dan melakukan pengabdian masyarakat.

Bukan itu saja, sebagian guru di Indonesia bahkan dinyatakan tidak layak mengajar. Persentase guru menurut kelayakan mengajar di berbagai satuan pendidikan sebagai berikut: Untuk SD yang layak mengajar hanya $21,07 \%$ (negeri) dan 28,94 \% (swasta), untuk SMP (sederajat) 54,12\% (negeri) dan 60,99\% (swasta), untuk SMA (sederajat) 65,29\% (negeri) dan 64,73 (swasta), serta SMK yang layak mengajar 55,49\% (negeri) dan 58,26 (swasta).

Kelayakan mengajar itu jelas berhubungan dengan tingkat pendidikan guru itu sendiri. Data Balitbang Depdiknas (1998) menunjukkan dari sekitar 1,2 juta guru SD/MI, hanya 13,8\% yang berpendidikan D-2 Kependidikan ke atas. Selain itu, dari sekitar 680.000 guru SLTP/MTs baru $38,8 \%$ yang berpendidikan D-3 Kependidikan ke atas. Di tingkat sekolah menengah, dari 337.503 guru, baru 57,8\% yang memiliki pendidikan S-1 ke atas. Di tingkat pendidikan tinggi, dari 181.544 dosen, baru $18,86 \%$ yang berpendidikan S-2 ke atas dan (3,48\%) berpendidikan S-3.16 
Walaupun guru atau pendidik bukan satu-satunya faktor penentu keberhasilan pendidikan, tetapi pembelajaran merupakan titik sentral pendidikan dan kualifikasi sebagai cermin kualitas. Tenaga pengajar memberikan andil sangat besar pada kualitas pendidikan yang menjadi tanggung jawabnya. Kualitas guru atau pengajar yang rendah juga dipengaruhi oleh masih rendahnya tingkat kesejahteraan guru.

Berbagai kritik dan analisis tersebut di atas mendeskripsikan kondisi pendidikan Islam yang selama ini berjalan di lapangan. Hal itu perlu segera dicarikan problem solving-nya, baik oleh guru pendidikan Islam itu sendiri, maupun para pemerhati dan pengembang pendidikan Islam.

\section{PARADIGMA BARU DALAM MENJAWAB TANTANGAN PENDIDIKAN ISLAM DI ERA GLOBALISASI}

Masyarakat Indonesia sekarang ini sedang dalam tahap belajar untuk hidup berdemokrasi dalam arti yang sebenarnya, sehingga memerlukan proses belajar dengan prioritas nilai-nilai tertentu seperti demokrasi, taat hukum, toleransi, akhlak dan moral yang anggun dan tanggung jawab sosial. Pembentukan masyarakat Indonesia yang demokratis, taat kepada hukum, beradab, bertanggung jawab dan berakhlak mulia memang perlu kerja keras, apalagi menghadapi tantangan-tantangan eksternal dalam era globalisasi dan era informasi. Dengan demikian, pendidikan yang memiliki peran sentral dalam upaya membangun dan mewujudkan masyarakat tersebut haruslah didasarkan pada paradigma-paradigma baru. Demikian halnya pengembangan pendidikan Islam haruslah didasarkan pada berbagai paradigma baru yang bertolak dari pengembangan manusia yang merdeka dan demokratis, yaitu manusia yang bertaqwa, berilmu pengetahuan, keterampilan, berakhlak dan bermoral tinggi, sehingga dapat verkarya dalam kehidupan masyarakat yang berjiwa kompetetif.

H.A.R. Tilaar mengatakan bahwa saat ini diperlukan suatu perubahan paradigma (paradigma shift) dari pendidikan untuk menghadapi proses globalisasi dan menata kembali kehidupan masyarakat Indonesia. Cita-cita era reformasi tidak lain ialah membangun suatu masyarakat madani. ${ }^{17}$ Oleh karena itu, arah perubahan paradigma baru pendidikan Islam diarahkan untuk terbentuknya masyarakat madani Indonesia.

Pada arah paradigma pendidikan dari paradigma lama ke paradigma baru, terdapat berbagai aspek mendasar dari upaya perubahan tersebut yaitu: pertama: arah paradigma lama terlihat lebih cenderung kepada: sentralistik, kebijakan lebih bersifat top down, orientasi pengembangan pendidikan lebih bersifat parsial, karena pendidikan didesain untuk sektor pertumbuhan ekonomi, stabilitas politik dan keamanan, serta teknologi 
perakitan. Peran pemerintah sangat dominan dalam kebijakan pendidikan dan lemahnya peran institusi pendidikan dan institusi non sekolah. Kedua, paradigma baru berorientasi pada pengembangan dengan ciri desentralistis, kebijakan pendidikan bersifat bottom up, orientasi pengembangan pendidikan lebih bersifat holistik. Artinya, pendidikan ditekankan pada pengembangan kesadaran untuk bersatu dalam kemajemukan budaya, kemajemukan berpikir, menjunjung tinggi nilai moral kemanusiaan dan agama, kesadaran kreatif, produktif, dan kesadaran hukum. Demikian pula dengan meningkatnya peran serta masyarakat secara kualitatif dan kuantitatif dalam upaya pengembangan pendidikan, pemberdayaan institusi masyarakat, seperti keluarga, LSM, pesantren, dan dunia usaha. ${ }^{18}$

Pandangan ini relevan dengan pendapat Winarno Surahmat bahwa pendidikan Islam sudah harus diupayakan untuk mengalihkan paradigma yang berorientasi ke masa lalu ke paradigma yang berorientasi ke masa depan. Orientasi tersebut mengalihkan paradigma pendidikan dan hanya mengawetkan kemajuan, ke paradigma yang merintis pendidikan. Pengalihan paradigma dari yang berwatak feodal ke paradigma yang berjiwa demokratis. ${ }^{19}$ Demikian pula mengalihkan paradigma dari pendidikan sentralisasi ke paradigma pendidikan desentralisasi, sehingga menjadi pendidikan Islam yang kaya dalam keberagamaan, dengan titik berat pada peran masyarakat dan peserta didik.

Fasli Jalal mengemukakan bahwa dalam proses pendidikan perlu dilakukan kesetaraan perlakuan sektor pendidikan dengan sektor lain, pendidikan berorientasi rekonstruksi sosial, pendidikan dalam rangka pemberdayaan umat dan bangsa, pemberdayaan infrastruktur sosial untuk kemajuan pendidikan Islam. Pembentukan kemandirian dan keberdayaan untuk mencapai keunggulan, penciptaan iklim yang kondusif untuk tumbuhnya toleransi dan konsensus dalam kemajemukan. Pandangan ini berarti diperlukan perencanaan terpadu secara horizontal (antarsektor) dan vertikal (antarjenjang-bottom up dan top down planning), pendidikan harus berorientasi pada peserta didik dan pendidikan harus bersifat multikultural serta pendidikan dengan perspektif global. ${ }^{20}$

Rumusan paradigma pendidikan tersebut, paling tidak memberikan arah sesuai dengan arah pendidikan, yang secara umum dituntut mengantarkan masyarakat menuju masyarakat madani Indonesia sesuai agenda reformasi di bidang pendidikan. Agenda dimaksud adalah masyarakat yang religius, demokratis, dan tangguh menghadapi lingkungan global.

Pandangan tersebut di atas sesuai dengan pandangan Mansour Fakih yang berpendapat bahwa mau tidak mau pendidikan Islam harus meninggalkan paradigma lama menuju ke paradigma baru, berorientasi pada 
masa depan, merintis kemajuan, berjiwa demokratis, bersifat desentralistis, berorientasi pada peserta didik, bersifat kultural dan berorientasi pada perspektif global. Dengan demikian, akan terbentuk pendidikan yang berkualitas dalam menghadapi tantangan perubahan global menuju terbentuknya masyarakat madani Indonesia. Pada tataran konsep, pendidikan baik formal maupun non formal pada dasarnya memiliki peran penting melegitimasi bahkan melanggengkan sistem dan struktur sosial yang ada dan sebaliknya pendidikan merupakan proses perubahan sosial. Tetapi, peran pendidikan terhadap sistem dan struktur sosial tersebut, sangat bergantung pada paradigma pendidikan yang mendasarinya. ${ }^{21}$

Berdasarkan pandangan di atas, maka peran pendidikan Islam mestinya bukan hanya dipahami dalam konteks kepentingan anak dilayani melalui interaksi pendidikan, tetapi juga dalam konteks kepentingan masyarakat. Dalam hal ini, termasuk masyarakat bangsa, negara, dan bahkan juga kemanusiaan pada umumnya, sehingga pendidikan Islam integratif antara proses pembelajaran di sekolah dengan belajar di masyarakat.

Upaya membangun pendidikan Islam berwawasan global tentu saja bukan persoalan mudah, karena pada waktu bersamaan pendidikan Islam harus memiliki kewajiban untuk melestarikan, menanamkan nilai-nilai ajaran Islam dan di pihak lain berusaha menanamkan karakter budaya nasional Indonesia dan budaya global. Akan tetapi, upaya membangun pendidikan Islam yang berwawasan global dapat dilaksanakan dengan langkah-langkah yang terencana dan strategis. Misalnya, bangsa Jepang diketahui bahwa mereka tetap merupakan bangsa yang mengglobal dan tanpa kehilangan karakternya sebagai suatu bangsa yang maju dan tetap kental dengan nilai-nilai tradisi dan nilai-nilai religius. Dengan contoh bangsa Jepang, maka pembinaan dan pembentukan nilai-nilai Islam tetap relevan, bahkan tetap dibutuhkan bagi masyarakat Indonesia dalam menghadapi tantangan global menuju masyarakat madani Indonesia. Hal ini senada dengan pendapat Fasli Jalal bahwa peran pendidikan sangatlah sentral dalam kehidupan masyarakat yang senantiasa mengalami pergeseran, sementara sistem sosial, politik dan ekonomi bangsa selalu menjadi penentu dalam penetapan dan pengembangan peran pendidikan. ${ }^{22}$

Secara filosofis, dari pendapat tersebut di atas, pendidikan harus dikembangkan berdasarkan tuntutan acuan perubahan tersebut dan berdasarkan karakteristik masyarakat yang demokratis. Sedangkan untuk menghadapi kehidupan global, proses pendidikan Islam yang diperlukan adalah mampu mengembangkan sikap inovatif yang berkualitas.

Berdasarkan pemikiran tersebut maka pendidikan harus mulai berbenah diri dengan menyusun strategi untuk dapat menyongsong dan dapat 
menjawab tantangan perubahan tersebut. Apabila tidak, pendidikan Islam akan tertinggal dalam persaingan global.

Untuk menyusun strategi dalam menjawab tantangan perubahan tersebut, paling tidak harus memperhatikan beberapa ciri sebagai berikut:

- Pendidikan Islam diupayakan lebih diorientasikan atau lebih menekankan pada upaya proses pembelajaran (learning) dari pada mengajar (teaching).

- Pendidikan Islam lebih diorganisasi dalam suatu struktur yang lebih fleksibel.

- Pendidikan Islam dapat memperlakukan peserta didik sebagai individu yang memiliki karakteristik khusus dan mandiri, dan

- Pendidikan Islam merupakan proses yang berkesinambungan dan senantiasa berinteraksi dengan lingkungan. ${ }^{23}$

Menurut analisis penulis, keempat ciri di atas dapat disebut paradigma pendidikan yang sistematis, yang menuntut pendidikan sebagai suatu proses yang tidak dapat dilepaskan dari perkembangan dan dinamika masyarakat. Pendidikan dalam pelaksanaannya, senantiasa mengaitkan proses pendidikan dengan kebutuhan masyarakat pada umumnya dan dunia kerja pada khususnya. Keterkaitan ini memiliki arti bahwa peserta didik tidak hanya ditentukan oleh apa yang mereka lakukan di lingkungan sekolah, melainkan peserta didik juga ditentukan oleh apa yang mereka kerjakan di dunia kerja dan di masyarakat pada umumnya. ${ }^{24}$

Pernyataan ini dapat dipahami bahwa dalam pengembangan pendidikan lebih ditekankan melalui kombinasi terpadu antara tuntutan kebutuhan masyarakat, dunia kerja, pelatihan, dan pendidikan formal persekolahan. Dengan demikian, sistim pendidikan akan mampu menghasilkan lulusan yang memiliki kemampuan yang memiliki fleksibilitas tinggi untuk menyesuaikan dengan tuntutan masyarakat yang senantiasa berubah dengan cepat. Tentu saja hal ini tidak terlepas dari pembenahan kurikulum.

Terkait dengan pandangan tersebut di atas, Mastuhu lebih mempertegas bahwa paradigma baru pendidikan Islam yang dimaksud di sini adalah pemikiran yang terus-menerus harus dikembangkan melalui pendidikan untuk merebut kembali kepemimpinan iptek, sebagaimana zaman dulu. Pencarian paradigma baru dalam pendidikan Islam dimulai dari konsep manusia menurut Islam, pandangan Islam terhadap iptek, dan setelah itu baru merumuskan konsep atau sistem pendidikan Islam secara utuh. ${ }^{25}$

Sementara itu, Hujair berpandangan bahwa pendidikan Islam harus diarahkan kepada dua dimensi: dimensi dialektika (horizontal), yaitu pendidikan hendaknya dapat mengembangkan pemahaman tentang kehidupan 
manusia dalam hubungannya dengan lingkungan sosialnya dan manusia harus mampu mengatasi tantangan dunia sekitarnya melalui pengembangan iptek; dan dimensi ketundukan vertikal, yaitu pendidikan selain sarana untuk memantapkan, memelihara sumber daya alam dan lingkungannya, juga memahami hubungannya dengan Sang Maha Pencipta, yaitu Allah swt. ${ }^{26}$

Dari beberapa analisis di atas, dapat dipahami bahwa pendidikan Islam yang diinginkan untuk dikembangkan adalah pendidikan yang menghilangkan atau tidak ada dikotomi antara ilmu dan agama, serta ilmu tidak bebas nilai tetapi bebas dinilai. Selain itu, agama diajarkan dengan bahasa ilmu pengetahuan.

Lodge dalam Muhaimin mengemukakan bahwa pendidikan merupakan persoalan hidup dan kehidupan, dan seluruh proses hidup dan kehidupan manusia adalah proses pendidikan. Karenanya, pendidikan Islam pada dasarnya hendak mengembangkan pandangan hidup islami, yang diharapkan tercermin dalam sikap hidup dan keterampilan hidup orang Islam. ${ }^{27}$

Mencermati beberapa pandangan tentang paradigma pendidikan Islam kini dan di sini (sekarang di Indonesia), maka mau tidak mau persoalan konsep dualisme dikotomi pendidikan harus segera ditumbangkan dan dituntaskan, baik pada tataran filosofis-paradigmatik maupun teknis departemental. Persoalan integrasi ilmu dan agama dalam satu sistem pendidikan ini memang tidak mudah, melainkan harus atas dasar pemikiran filosofis yang kuat, sehingga tidak terkesan hanya sekedar tambal sulam saja. Langkah awal yang harus dilakukan adalah mengadakan upaya perubahan sistem pendidikan yang dirumuskan dalam kerangka dasar filosofis pendidikan, tentu saja dengan melalui pembenahan kurikulum yang kuat dan matang sehingga tidak terjadi kurikulum pendidikan yang mati suri kalau tak hendak dikatakan "lā yamūtu wa lā yahyā" (mati segan hidup tidak mau).

\section{PENUTUP}

Bertolak dari berbagai pandangan tentang beberapa problematika pendidikan Islam kini dan di sini maka dapat ditarik "benang merahnya" yaitu: Pertama, masih adanya problem konseptual-teoritis atau filosofis yang kemudian berdampak kepada persoalan operasional praktis. Kedua, persoalan konseptual-teoritis ini ditandai dengan adanya paradigma dikotomi dalam dunia pendidikan Islam, antara agama dan bukan agama, wahyu dan akal, serta dunia dan akherat. Ketiga, kurangnya respons pendidikan Islam terhadap realitas sosial. Keempat, penanganan terhadap 
masalah ini hanya secara parsial, tidak dengan secara holastik, integral, dan komprehensif.

Pada arah paradigma pendidikan dari paradigma lama ke paradigma baru, terdapat berbagai aspek mendasar dari upaya perubahan tersebut yaitu: Pertama, pada paradigma lama terlihat upaya pendidikan lebih cenderung kepada sentralistis, kebijakan lebih bersifat top down, orientasi pengembangan pendidikan lebih bersifat parsial, karena pendidikan didesain untuk sektor pertumbuhan ekonomi, stabilitas politik dan keamanan, serta teknologi perakitan non sekolah. Kedua, paradigma baru, berorientasi pengembangan pada desentralistis, kebijakan pendidikan bersifat bottom up, orientasi pengembangan pendidikan lebih bersifat holistis.

\section{CATATAN AKHIR:}

1. Fahmi Lukman, http://www.icmimuda.org/indeks.php?opsion=comcontent \&task=view\&id=19\&Item, diakses tanggal 16 April 2008.

2. Departemen Agama RI. Al-Qur'an dan Terjemahnya, Semarang: CV. Asy-Syifa, 1998, h. 326.

3. Departemen Agama RI. Al-Qur'an dan Terjemahnya, h. 223.

4. Yaumi C.A. Achir, Reformasi Pendidikan Sebagai Upaya Memaksimalkan Hasil Pendidikan. dalam Dawam Rahardjo (ed), Keluar dari Kemelut Pendidikan Nasional, cet. I; Jakarta: PT. Intermasa, 1997 , h. 120.

5. Yaumi C.A. Achir, Reformasi Pendidikan Sebagai Upaya Memaksimalkan Hasil Pendidikan, h. 121

6. Ainurrafiq Dawam, "Pendidikan Islam Indoenesia Kini", Makalah, disampaikan dalam Seminar Nasional Pendidikan di UIN Yogyakarta, tgl. 12 April 2006. h. 7 .

7. Undang-undang Sistem Pendidikan Nasional Nomor 20 Tahun 2003, cet. III; Jakarta: Pustaka Pelajar, 2007, h. 8.

8. Briyan S. Turner, Weber and Islam, dialih bahasakan oleh G.A. Ticoalu dengan judul Sosiologi Islam, suatu Telaah Analitis atas Tesa Sosiologi Weber, Jakarta: CV. Rajawali, 1984, h. 314.

9. Briyan S. Turner, Weber and Islam, h. 316.

10 Azyumardi Azra, Pendidikan Islam Tradisi dan Modernisasi Menuju Milenium Baru, Jakarta: Logos, 1999, h. 85.

11. Muhaimin, Dakwah Islam di Tengah Transformasi Sosial, Surabaya: Karya Abditama, t.t., h. 149-151.

12. Muhaimin dan Abd. Mujib, Pemikiran Pendidikan Islam: Kajian Filosofis dan Kerangka Dasar Operasionalnya, Bandung: Trigenda Karya, 1993, h. 83.

13. Muhaimin dkk., Paradigma Pendidikan Islam; Upaya Mengefektifkan Pendidikan Agama Islam di sekolah, cet. II; Bandung: PT. Remaja Rosdakarya, 2002, h. 106.

14. Komaruddin Hidayat, Memetakan Kembali Struktur Keilmuan Islam. Dalam Fuaduddin dan Cik Hasan Bisri (ed.), Dinamika Pemikiran Islam di Perguruan Tinggi: Wacana tentang Pendidikan Agama Islam, Jakarta: Logos, 1999, h. 63. 
15. Harun Nasution, Islam Rasional: Gagasan dan Pemikiran, Bandung: Mizan, 1995, h. 428.

16. Pendidikan di Indonesia: Masalah dan Solusinya http://www.mi.fmipa.ugm. ac.id/new/?p=121 diakses tanggal, 9 Mei 2008.

17. H.A.R. Tilaar, Pendidikan, Kebudayaan, dan Masyarakat Madani Indonesia, Strategi Reformasi Pendidikan Nasional, Bandung: Remaja Rosdakarya Offset, h. 168.

18. Fasli Jalal, Reformasi Pendidikan dalam Konteks Otonomi Daerah, Yogyakarta: Adicita, 2001, h. 5.

19. Winarno Surahmat, Pendidikan Islam, Demokratisasi dan Masa Depan Bangsa, Jurnal Kajian Ma'rifah, Volume 4/tahun 1997, h.15.

20. Fasli Jalal, Reformasi Pendidikan dalam Konteks Otonomi Daerah, h. 7.

21. Mansour Fakih, Pendidikan Popular Membangun Kesadaran Kritis, Yogyakarta: Pustaka Pelajar, 2000, h. 18

22. Fasli Jalal, Reformasi Pendidikan dalam Konteks Otonomi Daerah, h. 6.

23. Zamroni, Paradigma Pendidikan Masa Depan, Yogyakarta: Bigraf Publishing, 2000, h. 9.

24. Zamroni, Paradigma Pendidikan Masa Depan, h. 10.

25. Mastuhu, Pemberdayaan Sistem Pendidikan Islam, Jakarta: Logos, 1999, h. 15.

26. Hujair A.H. Sanaky, Studi Pemikiran Pendidikan Islam Modern, Jurnal Pendidikan Islam, Konsep dan Implementasi, Volume V Th. IV, ISSN: 0853-7437, Yogyakarta: FIAI UII, 1999, h. 11.

27. Muhaimin dkk., Paradigma Pendidikan Islam, h. 39.

\section{DAFTAR PUSTAKA:}

Achir, Yaumi C.A.. Reformasi Pendidikan Sebagai Upaya Memaksimalkan Hasil Pendidikan dalam Dawam Rahardjo (ed). Keluar dari Kemelut Pendidikan nasional. Cet. I; Jakarta: PT. Intermasa, 1997.

Azra, Azyumardi. Pendidikan Islam Tradisi dan Modernisasi Menuju Milenium Baru. Jakarta: Logos, 1999.

Dawam, Ainurrafiq. Pendidikan Islam Indoenesia Kini (Makalah) disampaikan dalam Seminar Nasional Pendidikan di UIN Yogyakarta , tgl. 12 April 2006.

Departemen Agama RI. Al-Qur'an dan terjemahnya. Semarang: CV. Asy-Syifa, 1998.

Fakih, Mansour. Pendidikan Popular Membangun Kesadaran Kritis. Yogyakarta: Pustaka Pelajar, 2000.

H.A.R. Tilaar. Pendidikan, Kebudayaan, dan Masyarakat Madani Indonesia, Strategi Reformasi Pendidikan Nasional. Bandung: Remaja Rosdakarya Offset.

Hidayat, Komaruddin. Memetakan Kembali Struktur Keilmuan Islam dalam Fuaduddin dan Cik Hasan Bisri (ed.) Dinamika Pemikiran Islam di Perguruan Tingg: Wacana tentang Pendidikan Agama Islam. Jakarta: Logos, 1999.

Jalal, Fasli. Reformasi Pendidikan dalam Konteks Otonomi Daerah. Yogyakarta: Adicita, 2001.

Lukman, H. Fahmi. http://www.icmimuda.org/indeks.php?opsion=com-content \&task=view\&id=19\&Item, disadur tanggal 16 April 2008

Mastuhu. Pemberdayaan Sistem Pendidikan Islam. Jakarta: Logos, 1999. 
Muhaimin dan Abd. Mujib. Pemikiran Pendidikan Islam: Kajian Filosofis dan Kerangka Dasar Operasionalnya. Bandung: Trigenda Karya, 1993.

-------, Dakwah Islam di tengah Transformasi Sosial. Surabaya: Karya Abditama, t.t.

-------, dkk. Paradigma Pendidikan Islam; Upaya Mengefektifkan Pendidikan Agama Islam di sekolah. cet. II; Bandung: PT. Remaja Rosdakarya, 2002.

Nasution, Harun. Islam Rasional: Gagasan dan Pemikiran. Bandung : Mizan, 1995.

Pendidikan di Indonesia: Masalah dan solusinya http://www.mi.fmipa.ugm.ac.id/ new $/$ ? $=121$

Sanaky, Hujair A.H. Studi Pemikiran Pendidikan Islam Modern; Jurnal Pendidikan Islam, Konsep dan Implementasi, Volume V Th. IV, ISSN: 0853-7437. Yogyakarta : FIAI UII, 1999.

Surahmat, Winarno. Pendidikan Islam, Demokratisasi dan Masa Depan Bangsa, Jurnal Kajian Ma'rifah, Volume 4/tahun 1997.

Turner, Briyan S. Weber and Islam, dialih bahasakan oleh G.A. Ticoalu dengan judul Sosiologi Islam, suatu Telaah Analitis atas Tesa Sosiologi Weber. Jakarta: CV. Rajawali, 1984.

Undang-undang Sistem Pendidikan Nasional Nomor 20 Tahun 2003. Cet. III; Jakarta: Pustaka Pelajar, 2007.

Zamroni. Paradigma Pendidikan Masa Depan. Yogyakarta: Bigraf Publishing, 2000. 